\title{
The influence of the iodinate contrast medium during CT: Single center experience - Development of two competitive in-house methods for automated quantification of DDSB
}

\author{
Klimentina Trajkova ${ }^{1}$, Ivana Dilevska ${ }^{1}$, Rumenka Petkovska ${ }^{2}$, Dejan Trajkov $^{1,3}$, \\ Thomas Kroneis ${ }^{4}$, Wolfgang Schwinger ${ }^{5}$, Erich Sorantin ${ }^{1}$ \\ ${ }^{I}$ Division of Pediatric Radiology, Department of Radiology, Medical University Graz, \\ Auenbruggerplatz 34 A - 8036, 8010 Graz, Austria \\ ${ }^{2}$ Institute of Applied Chemistry and Pharmaceutical Analysis, Faculty of Pharmacy, \\ Ss. Cyril and Methodius University, Majka Tereza 47, 1000 Skopje, \\ Republic of North Macedonia \\ ${ }^{3}$ Institute of Immunobiology and human genetics, Medical faculty, \\ Ss. Cyril and Methodius University, 50 Division 6, 1000 Skopje, Republic of North Macedonia \\ ${ }^{4}$ Division of Cell Biology, Histology and Embryology, Gottfried Schatz Research Center, \\ Medical University Graz, Neue Stiftingtalstraße 6, 8010 Graz, Austria \\ ${ }^{5}$ Division of pediatric hematology/oncology, Department of Paediatrics and Adolescent Medicine, \\ Medical University Graz, Auenbruggerplatz 34/2 - 8036, 8010 Graz, Austria
}

Received: April 2019; Accepted: May 2019

\begin{abstract}
DNA damage induced by ionizing radiation may ultimately lead to cell death or initiate cancer cells development. Today it is difficult to estimate what the actual damage to the human body will be, given the fact that today in the world the number of diagnostic procedures using radiation and iodine contrast media is increasing, and the existence of a number of factors that can affect the radiation dose in vivo. At the same time, development of new methods is required, which can determine in a much shorter time what will be the effect of diagnostic radiation on the DNA molecule. For these purposes we develop two competitive inhouse methods for automated quantification of DNA double strand brakes (DDSB) in peripheral blood lymphocytes: immunofluorescence determining of $\gamma \mathrm{H} 2 \mathrm{AX}$ with stained microscopic slides and determining the occurrence of DDSB with the flow cytometry. Our initial results shown that computed tomography (CT) can cause damage in the DNA molecule in the form of DDSB, the existence of linear dependence with the increase in low and high range of CTDI and the number of $\gamma \mathrm{H} 2 \mathrm{AX}$, and that iodine contrast media can increase the occurrence of DNA double strand brakes.
\end{abstract}

Keywords: CT examinations, ICM, immunofluorescence, flow cytometry, DDSB

\section{Introduction}

Since their discovery until now, X-rays have been used for many things. In medicine they are used for diagnostic procedures, interventional radiology and in radiation therapy. Because of this they represent the largest man-made source of exposure to radiation in humans (Brenner, 2004; Brenner \& Elliston, 2004; Doll \& Wakeford, 1997; Fuchs \& Sox, 2001; Gilbert, 2001;

\footnotetext{
*klimentinatrajkova@gmail.com
} 
ICRP, 1991; United Nations Scientific Committee on the Effects of Atomic Radiation, 2000). According to some authors, this medical X-ray exposure account for 14-20\% of the total annual exposure worldwide (Haaga, 2001; Herzog \& Rieger, 2004; Nickoloff \& Alderson, 2001). Most of this medical radiation are due to computed tomography (Berrington \& Rieger, 2004; Haaga, 2001; Nickoloff \& Alderson, 2001). It is considered that in Germany the cumulative risk of approximately $1.5 \%$ for carcinomas in people over 75 years of age is due to $\mathrm{X}$ radiation use in medical purposes (Deinzer et al., 2014). In the United States, about 6000 new cases of carcinoma occur each year as a result of the application of radiation to medical purposes (Haaga, 2001; Herzog \& Rieger, 2004; Nickoloff \& Alderson, 2001; Thomsen \& Morcos, 2003). In the UK application of a radiation dose in medical procedures leads to an increase in the risk of cancer for $1 \%$ (Kendall et al., 2006). Children are thought to be even up to 10 times more susceptible than adults (Rassow et al., 2000; United Nations Scientific Committee on the Effects of Atomic Radiation, 2000). It has been long recognized that ionizing radiation (X-rays, $\Upsilon$-rays, $\alpha$ particles, as well as heavy ions) can lead to the occurrence of various substantial damage of the DNA molecule in the form of single-strand breaks, double-strand breaks, as well as base damages (Berrington \& Rieger, 2004). Of greatest interest is the occurrence of double breaks interruptions in the DNA molecule, which can lead to genetic instability and the occurrence of carcinogenesis (Kinner et al., 2008). These double DNA breaks are created either due to the direct action of X-rays on DNA and creation of DNA radicals or the creation of radicals due to radiolysis of the water (Bernard et al., 2013). These radicals react with atoms and molecules in cells and cause single-strand breaks, double-strand breaks, and base damages, causing an increase in the risk of malignant disease (Berrington \& Rieger, 2004; Joubert et al., 2008).

Most frequently the "Linear No Threshold Theory" is favored (Wakeford, 2005). Other theories emphasize the "Hormesis", meaning the positive effect of low dose radiation on DNA repair (Doss, 2013). In a number of imaging applications, and especially in computerized tomography, to better visualize the findings iodine contrast agents are used, because they increase the contrast of the vessels, structures or liquids. According to some studies, over a year, 8 million liters of iodine contrast mediums (ICM) are used worldwide (Dusal \& Reiner, 2009). Usage of ICM can lead to an increase in DNA damage (Gould et al., 2016; Grudzenski et al., 2010; Pathe et al., 2011; Piechowiak et al., 2015), especially if used in concentrations greater than $17.5 \mathrm{mg} / \mathrm{mL}$ (Gould et al., 2016). In vitro studies demonstrated an increase of $25 \%$ in the number of DNA double strand brakes (DDSB) when using ICM, as to those without ICM application (Pathe et al., 2011). However, other investigations indicated that there is no increase in the number of DNA impairments after the use of ICM (Beels et al., 2012; Deinzer et al.,
2014, Grudzenski et al., 2009; Jost et al., 2009; Joubert et al., 2005; Vandevoorde et al., 2015), or that there is statistically insignificant increase (Wang et al., 2017). The mechanism by which ICM causes such changes is not yet known (Joubert et al., 2005). Furthermore, up to now there is no agreement about the mechanism how $\mathrm{x}$-ray based clinical imaging can cause DNA damage or even mutations. Several theories about the interaction of ionizing radiation on the DNA exists in the low dose range (https://en.wikipedia.org/wiki/Linear_nothreshold_model, accessed January 18, 2017).

Today, the measurement of the phosphorylated histone variant of $\gamma \mathrm{H} 2 \mathrm{AH}$ is widely used in the world as a reliable and sensitive marker for measuring the number of DNA double-strand breaks after the exposure to ionizing radiation (Bells et al., 2009; Beels et al., 2012; Jeggo \& Lobrich, 2006; Lobrich et al., 2005; Mah et al., 2011; Roch-Lefevre et al., 2010; Rothkamm et al., 2007; Rothkamm \& Horn, 2009; Zhang et al., 2016).

Medical diagnostic procedures involving CT and iodine contrast media are increasing year by year. This is largely due to the improvement in detector width of the apparatus itself, associated with the faster rotational time thus enabling greater volume coverage. Some studies indicate that increasing number of CT scans and radiation doses can be associated with the cancer risks in adults and particularly in children (Brenner \& Hall, 2007), since the computed tomography delivers at least 100 times more radiation than plain $\mathrm{x}$-rays. In the pediatric radiology community hazards and long-term effects of ionizing radiation, including cancer induction, are well percepted and are supported by empirical studies (Mathews et al., 2013).

DNA damage induced by ionizing radiation may ultimately lead to cell death or initiate cancer cells development. For these reasons, molecular-level thorough understanding of fundamental mechanisms behind the processes leading to DNA damage may certainly be of substantial importance in cancer treatment and perhaps even prevention. In most studies, the effects of diagnostic doses of CT radiation are examined in vitro using the ionizing chambers and cell cultures. In such circumstances it is difficult to estimate what the actual damage to the human body will be, given the existence of a number of factors that can affect the radiation dose in vivo. At the same time, development of new methods is required, which can determine in a much shorter time what will be the effect of diagnostic radiation on the DNA molecule, compared to the standard methods. Especially knowing that doses above $50 \mathrm{mGy}$ can triple the risk of occurrence of leukemia in children (Pearce et al., 2012).

Unfortunately, the examination of $\gamma \mathrm{H} 2 \mathrm{AH}$ naturally does not give the information about the position within the genome where DDSB's occur. Despite all these efforts the carcinogenic effected of repeated imaging using modalities utilizing ionizing radiation, like CT, can be evaluated but not explained. Detection of the appropriate 
genome areas, which are hit by ionizing radiation, could be a major step forward in understanding those mechanisms. Due to this, the need for developing new methods for the automatic determination of DDSB is growing. In order to get better understanding of mechanisms how radiation acts on DNA leading to DDSB's; to find the localization of DDSB's within the DNA - which will allow us to study and analyze those DNA parts in detail with molecular biologic and laboratory techniques; to get more insight why e.g. repeated imaging, utilizing ionizing radiation, increases cancer risk and how this can be prevented; and since in cancer therapy many cytostatic drugs provide their action by leading DDSB's more insights in this process could lead to more personalized therapy plans, thus reducing collateral damage.

This paper aims to show our initial results on the introduction of two competitive in-house methods for automated quantification of DDSB's and generation of a calibration curve - meaning dose $v s$. number of DDSB's, as well as to show the impact of ICM on the number of DDSB.

\section{Material and methods}

\section{In vitro irradiation}

In our examinations, as samples, we used $50 \mathrm{ml}$ of buffy coat (fraction of an anticoagulated blood sample that contains most of the white blood cells and platelets following density gradient centrifugation of the blood, (https://en.wikipedia.org/wiki/Buffy_coat, accessed May 10 , 2019) that contain only leucocytes, from normal healthy blood donors, obtained from the Department of Blood Group Serology and Transfusion Medicine at the Medical Faculty in Graz. The buffy coat was first divided in equal aliquots in 10 tubes of $50 \mathrm{ml}$. From these tubes we form 5 groups of 2 tubes each. The first group of 2 tubes was not irradiated and served as a control. The remaining 4 groups of 2 tubes each were irradiated with different doses according to the pre-prepared protocol. The range of radiation doses ranged subclinical dose to supraclinical doses (0.88-2153.6 mGy of Computed Tomography Dose Index) (https://en.wikipedia.org/wiki/ Computed_tomography_dose_index, accessed May 9, 2019). In the cases when we wanted to examine the effects of ICM on the occurrence of DDSB, into each of the test tubes of the four examined groups prior to irradiation 200 microliters of Iomerone 300, containing $61.24 \% \mathrm{w} / \mathrm{v}$ iomeprol equivalent to $30 \%$ iodine or $300 \mathrm{mg}$ iodine $/ \mathrm{mL}$ was added. Both, doses of irradiation and concentration of iodine contrast media correspond to those that we use daily in our clinical practice when working with pediatric cases. This quantity corresponds to the amount that is reach in the organism of pediatric patients immediately after intravenous administration All samples are irradiated at room temperature in 320-slice
CT Scan (Toshiba AquilionONE) based on the Roentgen rays, with the following imaging parameters: 80, 100 and $120 \mathrm{kV}, \mathrm{mA}$ range of $20-500$ and repetition of rotation time from 0.5 to $3.0 \mathrm{sec}$ in order to generate higher dosage. The dose-length product was calculated as the sum of the products of the CT dose index (CTDI) and the scan length for each phase.

\section{Lymphocyte separation}

After irradiation, all samples were first incubated for 15 minutes at $37{ }^{\circ} \mathrm{C}$ to allow sufficient time for DNA damage signaling and activating the mechanisms for repairing DNA damage (Roch-Lefevre, 2010), in order to correct the interruptions in the DNA molecules that can be repaired. Then we transferred the samples to $4{ }^{\circ} \mathrm{C}$ to stop the further acting on these DNA repair mechanisms. Then, each of the vials is diluted with a PBS up to a volume of $30 \mathrm{~mL}$. Afterward samples were placed on a ficol gradient (Ficoll-Paque ${ }^{\mathrm{TM}}$ PLUS, GE Healthcare) and centrifuged at $2000 \mathrm{rpm}$ at room temperature without a break. The resulting layer of mononuclear cells was transferred to a new tube and PBS was added to a $50 \mathrm{~mL}$ final volume. The tube is centrifuged at $1300 \mathrm{rpm}$ within 10 minutes. The supernatant is discarded, while the precipitate is resuspended in PBS to a concentration of $1 \times 10^{7}$ cells $/ \mathrm{mL}$.

\section{Immunofluorescence and microscopy}

An amount of $2-10^{6}$ cells were applied to microscope slides (Super-Frost WEISS, ROTH Karlsruhe) with a cytospin centrifuge at $500 \mathrm{rpm}$ for 10 minutes. Immediately afterwards, we performed cell fixation for 10 minutes at room temperature with freshly prepared $4 \%$ Formaldehyde (Sigma-Aldrich) in PBS. Then microscopic slides were washed 3 times in 10 minutes with PBS. Permeabilization and blocking were done in $0.2 \%$ Triton X-100 (Sigma-Aldrich) in PBS on plus $4{ }^{\circ} \mathrm{C}$. After peremeabilisation and blocking, the slides were washed 3 times in 10 minutes in 1\% BSA (Sigma, Life Science) in PBS. The primary staining with $\gamma \mathrm{H} 2 \mathrm{~A} . \mathrm{X}$ (Ser139) clone JBW301 (Millipore), diluted 1:1000 in Blocking Solution (1\% BSA and PBS) were done at $4{ }^{\circ} \mathrm{C}$ overnight in wet chamber. After the primary staining, the antibody was washed 3 times in 10 minutes with $1 \%$ BSA in PBS. Secondary staining was performed with Alexa Fluor 488, goat-anti mouse, diluted 1: 2000 in Blocking Solution (1\% BSA and PBS) for 1 hour in dark in wet chamber. After secondary staining slides were washed 4 times in 10 minutes with PBS on dark in washing baths covered with aluminum foil. Then, slides were carefully clean from washing solution without wiping off the cells and dried for 5-10 min. Dried slides were covered with cover glass coated with Fluoroshield ${ }^{\mathrm{TM}}$ with DAPI (Sigma, Life Science). In this way prepared slides were left to dry for 1 hour in dark at room temperature. After drying, microscopic slides were sealed with nail polish. 
The prepared glasses stood at $-20{ }^{\circ} \mathrm{C}$ until their analysis. Analyzes of the foci were carried out using the Zeiss ObserverZ1 microscope platform equipped with Zeiss filters sets FS01 (DAPI), FS17 (FITC) and FS20 (CY3) using a $63 \mathrm{x}$ objective. Scanning and initial pre-analytical image processing was done in ZEN software version 2.3 (Zeiss). Image analysis was performed in CellProfiler (v.2.2.0 rev ac0529e) to calculate the number of cells and the number of DDSB that occur per sample.

\section{Flow cytometry}

From each of the irradiated test tubes, before starting with the immunohistochemical staining, we took a sample for performing flow cytometry. Each of the samples was diluted with PBS until the number of WBC were below 5000 cells/microliter. Flow cytometry was performed on polystyrene tubes divided into three groups. The first group served as a control and contained only an irradiated sample and a physiological solution. In the second group of tubes, beside the irradiated sample, we added a mixture of fluorescently labelled IgG antibodies (marked with FITC, PC5.5, APC, APC-AF700, APC-AF750 and KrO). In the third group of tubes, beside the irradiated blood sample, we added a mixture of fluorescently labelled antibodies directed to surface CD markers for lymphocytes (CD19 PC5.5, CD8 APC, CD4 APC-AF700, CD3 APC-AF750 and CD45 KrO). After careful mixing, all the tubes were incubated for 15 minutes on ice in the dark. Following incubation, the test tubes were vortexed and fixed for 15 minutes on ice in the dark with IntraPrep Reagent 1 (Beckman Coulter). After fixing, in each tube 4 $\mathrm{mL}$ of PBS were added and centrifuged for 5 minutes at
$300 \mathrm{~g}$ to $4{ }^{\circ} \mathrm{C}$. The supernatant was decanted, and the IntraPrep Reagent 2 (Beckman Coulter) was added to the cells pellet for permeabilization. Permeabilization of the cells was carried out for 5 minutes on ice in the dark. For intracellular staining, after permeabilization, in the third group of tubes $\gamma \mathrm{H} 2 \mathrm{AX}-\mathrm{FITC}$ 1:10 with PBS was added. Intracellular staining took place for 2 hours in dark at 4 ${ }^{\circ} \mathrm{C}$. After incubation in all tubes $4 \mathrm{~mL}$ of PBS were added and centrifuged for 5 minutes at $300 \mathrm{~g}$. The supernatant was decanted, and fixative solution were added (IO Test 3 Fixative Solution, Beckman Coulter). Until measurement, the test tubes were stored in a refrigerator at $4{ }^{\circ} \mathrm{C}$. The analysis was performed using the Navios Flow Cytometer (Beckman Coulter). For the analysis of the foci, for determining the number of cells, as well as the number of foci that occur in one sample Kaluza Software Package (Beckman Coulter) was used. In all tubes, the number of signals (foci) in Th cells, Tc cells and B cells were measured.

The number of foci/100 cells obtained by immunofluorescence staining and flow cytometry will be used as a starting value in the identification of medical imaging induced DNA double strain brakes based on mathematical modelling.

\section{Results and Discussion}

Our initial results shown that CT can cause damage in the DNA molecule in the form of DDSB, when compared with control samples that are not irradiated (Figure 1, 2 and 3).

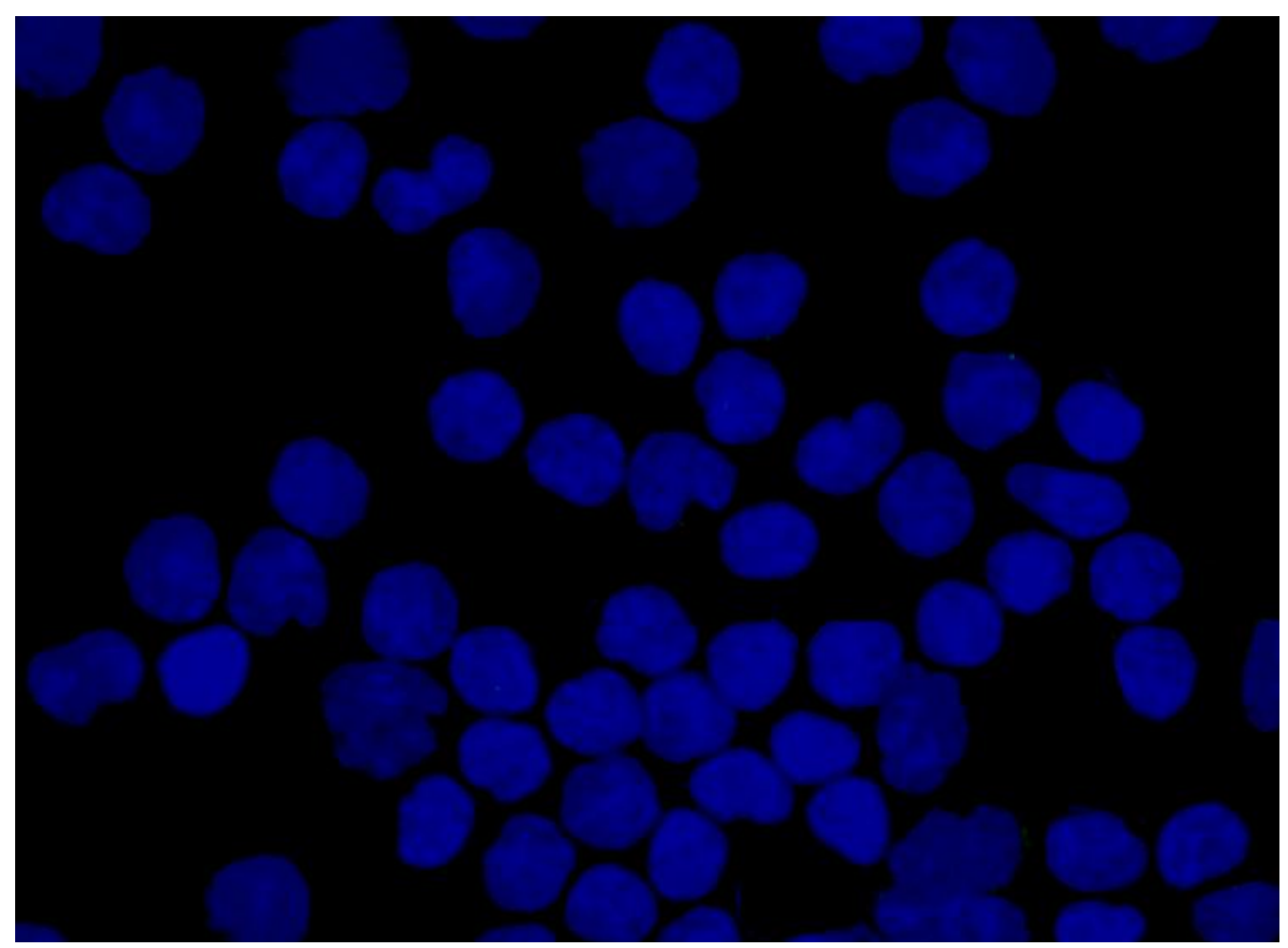

Fig. 1. $\gamma \mathrm{H} 2 \mathrm{AX}$ immunofluorescence staining of a native blood sample (before irradiation). 


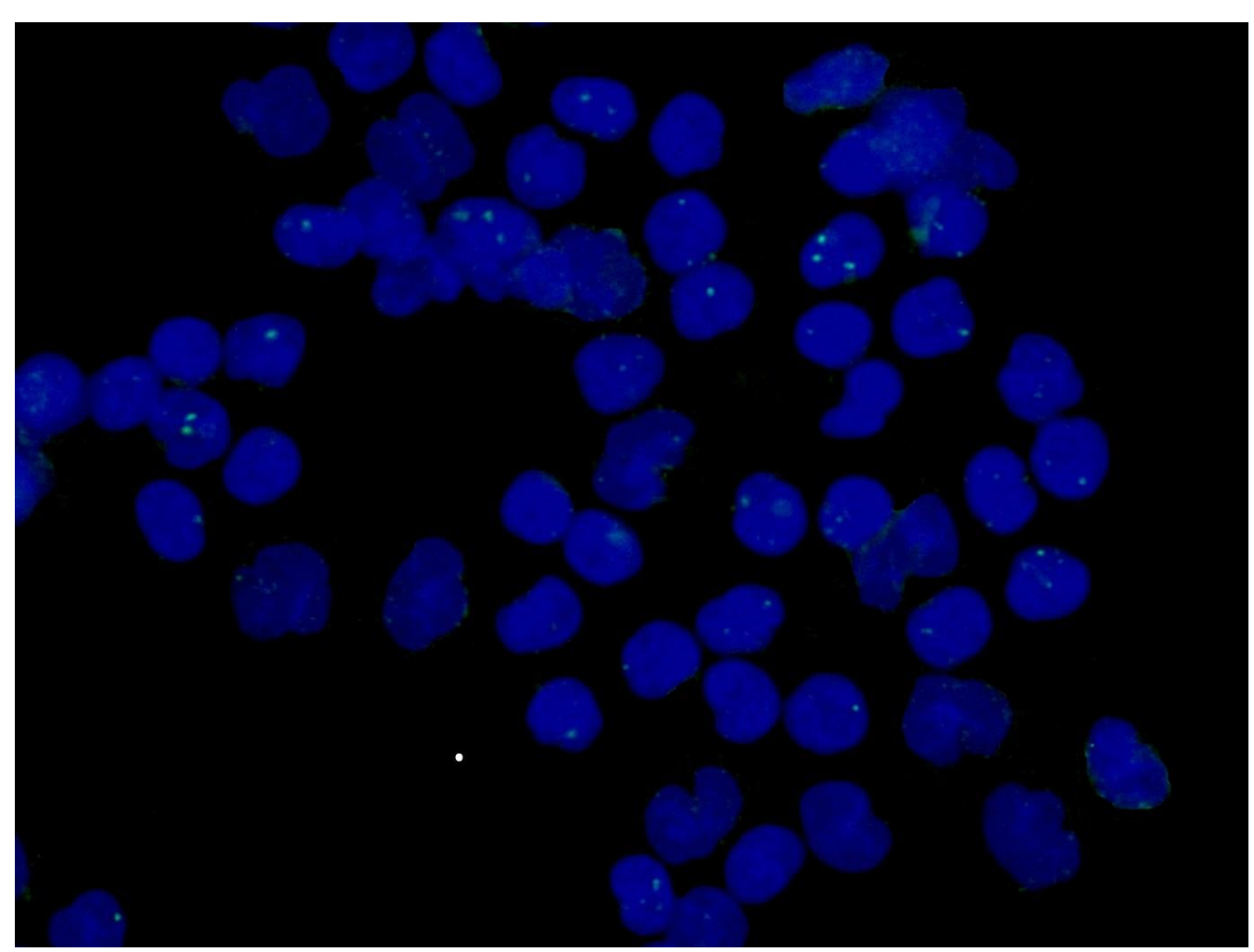

Fig. 2. $\quad \gamma \mathrm{H} 2 \mathrm{AX}$ immunofluorescence staining of a blood sample after CT irradiation with a CTDI of $88.12 \mathrm{mGy}$. Bright spots represent foci where DNA double strain breaks occurred.

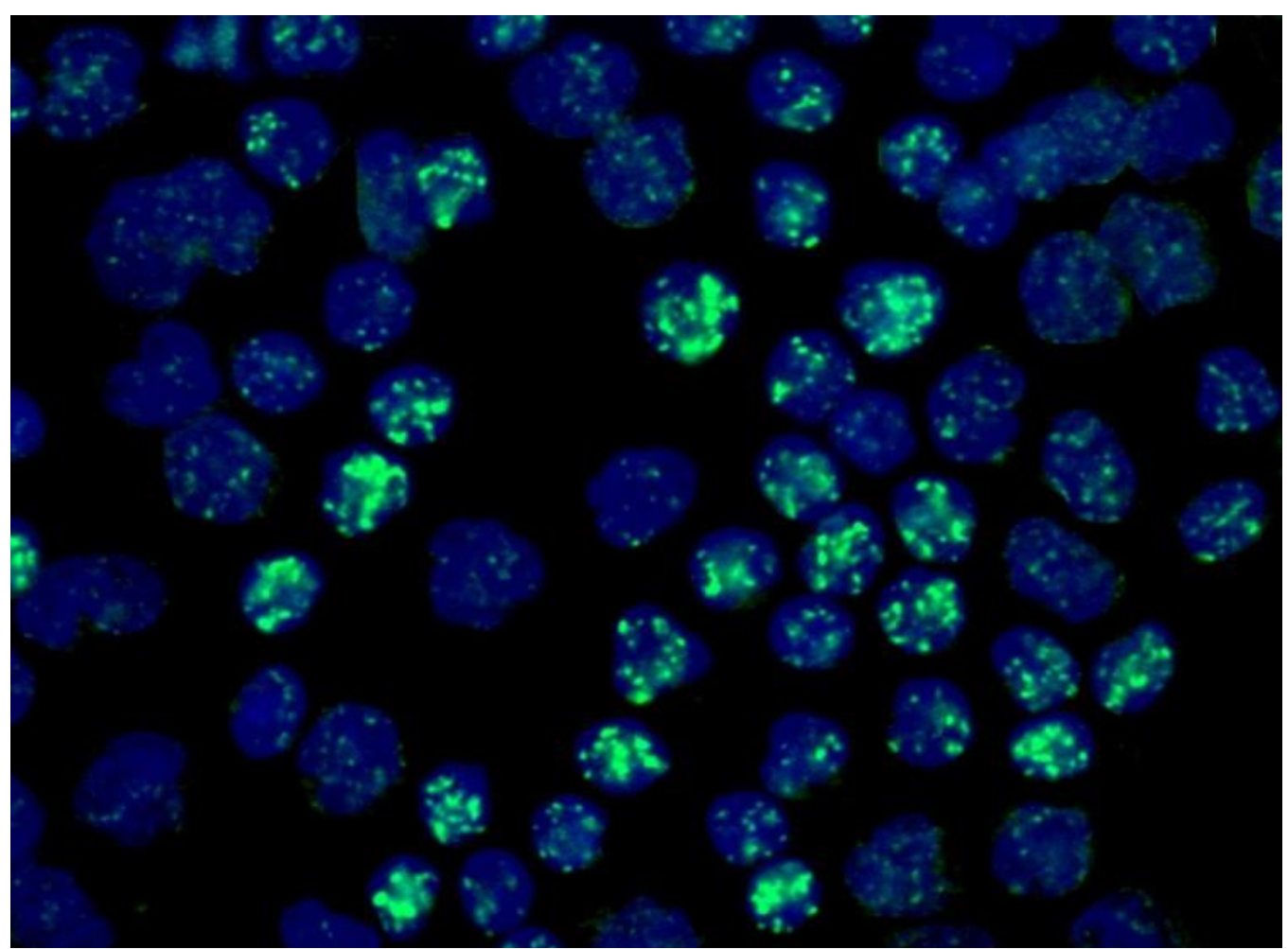

Fig. 3. $\gamma \mathrm{H} 2 \mathrm{AX}$ immunofluorescence staining of a blood sample after CT irradiation with a CTDI of $1615.3 \mathrm{mGy}$. Bright spots represent foci where DNA double strain breaks occurred. 


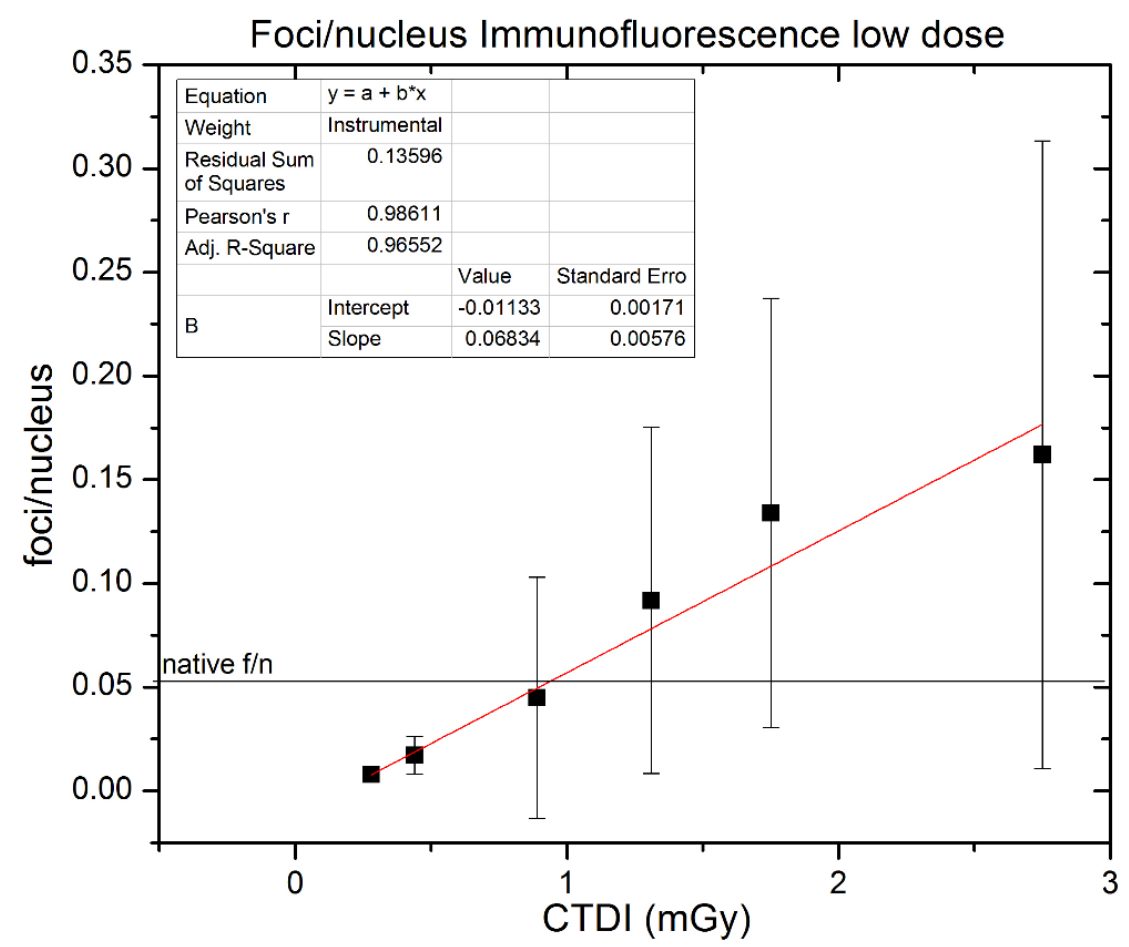

Fig. 4. Number of DDSB's in dependence to dose to low doses in CT with correlation of $\mathrm{R}^{2}=0.96$, CTDI: Computed Tomography Dose Index.

Today in medical institutions around the world thousands of diagnostic procedures using radiation are performed. It is thought that in recent decades the use of iodine contrast media has increased by about $800 \%$ (Deinzer et al., 2014). But until recently, when using these iodine contrast agents, only their nephrotoxicity and the ability to cause allergies were taken into account (Davidson \& Erdogan, 2008; Gueant-Rodrigez et al., 2006; Singh \& Daftary, 2008).

"Linear no threshold theory" assure us that there is no reliable radiation dose. Research has indicated the existence of a linear dependence between the increase in radiation dose and the risk of cancer (National Research Council. 2006. Health Risks from Exposure to Low Levels of Ionizing Radiation: BEIR VII Phase 2). This risk in children using ICM increases up to $19 \%$. Some studies have shown that the cumulative risk in children who are subjected to multiple CT examinations is 6.5\% (Johnson et al., 2014), while those who are subjected to heart catheterization are even 1 per 1000 (Beels et al., 2009). Our initial results obtained with immunofluorescence, we established the existence of linear dependence with the increase in low and high range of CTDI and the number of $\gamma \mathrm{H} 2 \mathrm{AX}$ in peripheral lymphocyte (Figure 4 and 5).

Besides better understanding of the molecularbiological damage and potential cancer induction, there is the vision that, by means of determining $\gamma \mathrm{H} 2 \mathrm{AX}$, could be a possibility to approximate the individual radiation sensitivity. Thus, triggering a more aggressive approach to optimization and stratification of imaging procedures utilizing ionizing radiation, strategies for "genome protection" as well as stimulating the development and optimization of alternatives. In addition, many chemotherapeutic drugs induce DNA double strain berakes and such an approximation could also assist in optimal dose adjustments of chemotherapeutics in pediatric oncologic patients.

When assessing the effect of ICM, it should always be taken into account, from which illness the patient is affected, and how this disease affects the occurrence of DDSB. In the literature there are a variety of data about the potential impact of ICM. However, even if in some of the papers has been found that ICM can cause some changes in the DNA molecule, the real nature of those changes is still not fully understood. It is still not known whether this damage is due to direct damage to the DNA molecule under the influence of radiation, due to the disruption of the mechanisms for DNA repairing or because of the direct cytotoxicity of ICM (Joubert et al., 2008). Such damages occur through a sequence of rather complex physicochemical processes. One part of the research suggests that these changes may be largely due to 
direct damage under the influence of radiation, without influencing on DNA repair (Rothkamm \& Horn, 2009). $\mathrm{X}$-ray radiation in medical diagnostic procedures leads to the appearance of the photoelectric effect, i.e. the absorption of the energy from the rays results in the emission of electrons from the $\mathrm{k}$-shell of the atoms. The energy that is generated in this way (Pradhan et al., 2009), can cause damage to the DNA molecule in two ways. Directly, by damaging covalent and hydrogen chemical bonds in the DNA molecule or indirectly, by radiolysis of the water from the irradiated place of the organism to its constituents. Because the radicals created in this way can donate or receive electrons, they can enter into complex interactions with surrounding tissues (Fisher-Bellman \& Bloomer, 2009). The chemical number of iodine used in medical diagnostic procedures is 53 and is much larger than all the same numbers of other elements on which the human body is based. This means that iodine is much more capable of releasing or receiving electrons compared to surrounding soft tissues, which would create a greater amount of free radicals. Especially when it is known that the absorption of energy in the $\mathrm{K}$-edge of iodine is in the domain of the energy value of the photons used in diagnostic procedures. This increased release or receive of electrons can also potentiate the Auger effect (Auger, 1975). In this effect, the transition of the electrons from the outer shells into one of the inner shells occurs. In this process of transition, either a photon is released, with an energy equivalent to the net difference between the outer and inner shell, or that energy causes the ejection of electrons out of the outer shell (Pradhan et al., 2009). Both, the photon and the ejection of electrons from the outer shell, cause the formation of free oxygen radicals capable of causing DNA damage. According to some authors, oxidative radicals similar to those produced in large-dose irradiation may also be induced in patients with prior treatment with $\mathrm{H}_{2} \mathrm{O}_{2}$, the conditions similar to those with oxidative stress (Grudzenski et al., 2010). According to these authors, a certain level of radiation energy is needed to trigger mechanisms for repairing the DNA molecule, which means that small radiation doses below 10 mGy are ineffective for such a thing (Grudzenski et al., 2010). Of course, all types of the previously outlined processes may take place in parallel. Due to the inherently molecular nature of all these processes, they are quantum in nature and their outcome depends on the topology of molecular potential energy hypersurface details and other inherently molecular properties. For that reason, a thorough in-depth understanding of DNA damage as a consequence of its interaction with ionizing radiation (in a direct or indirect manner) has to be based on molecular quantum mechanics and dynamics.

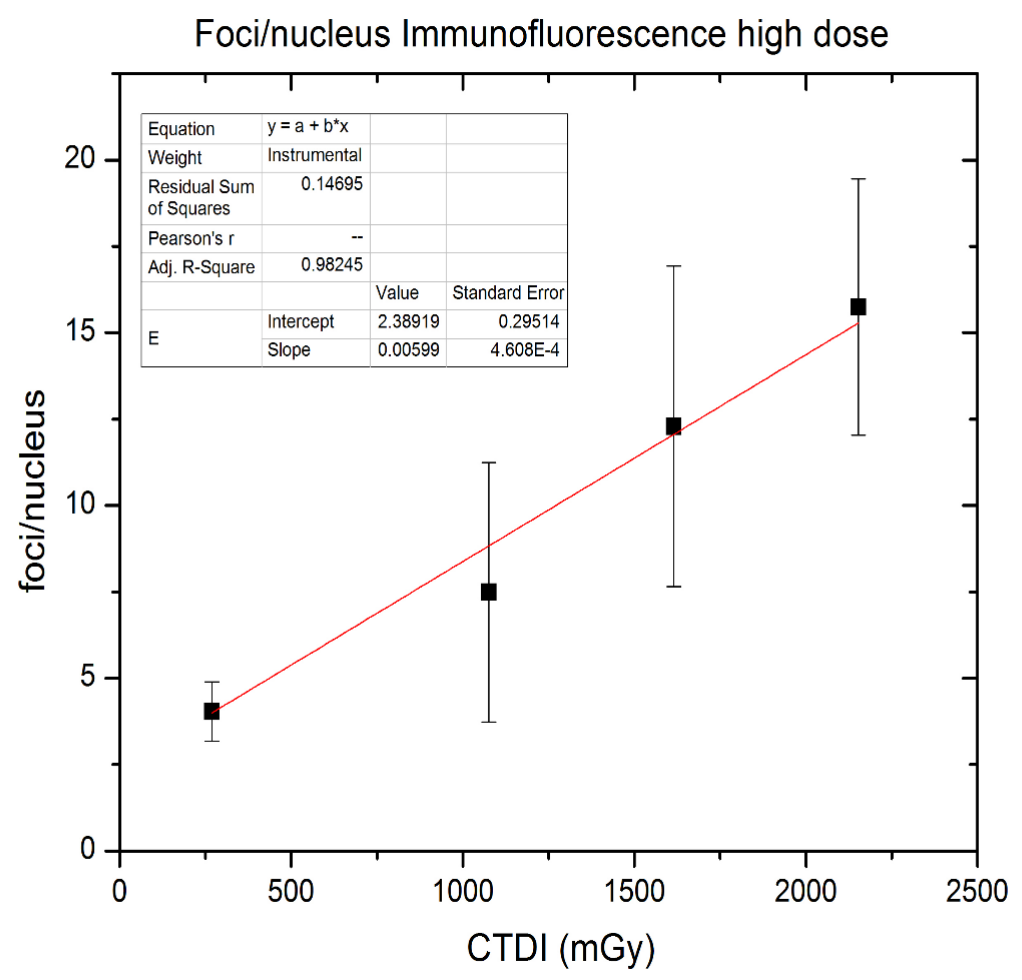

Fig. 5. Number of DNA double strain breaks in dependence to dose high CTDI range with correlation $\mathrm{R}^{2}=0.98$, CTDI: Computed Tomography Dose Index. 


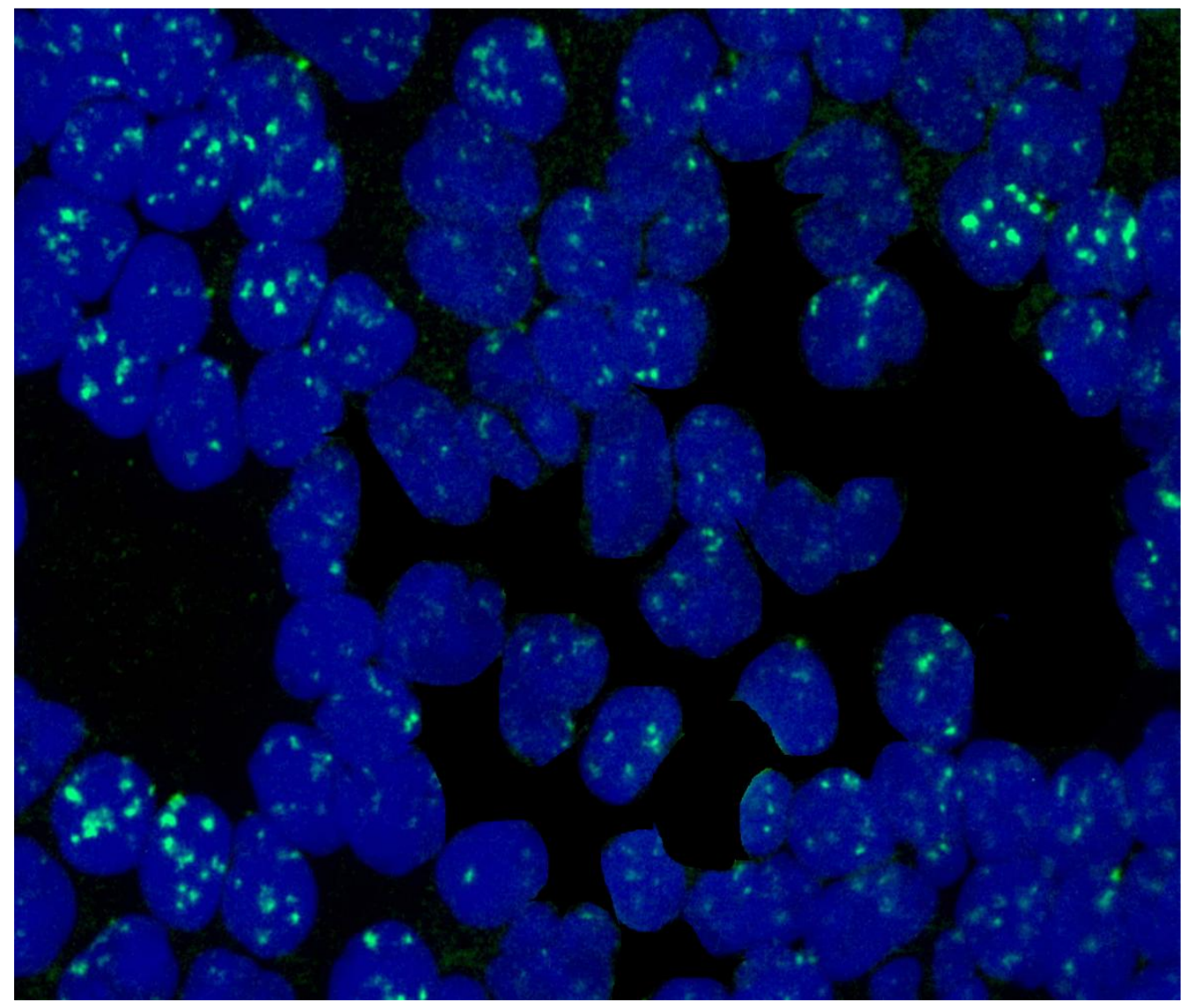

Fig. 6. $\gamma \mathrm{H} 2 \mathrm{AX}$ immunofluorescence staining of a blood sample with $7.5 \mathrm{mg}$ iodine per $\mathrm{mL}$ blood after CT irradiation. Bright spots represent foci where DNA double strain breaks occurred.

It seems that other factors and mechanisms may also affect the occurrence of damage to the DNA molecule in medical diagnostic procedures, without or with using iodine contrast agents. Proof of this are the most diverse results obtained in in vitro and in vivo studies done for these purposes. Some studies indicate that the ICM itself, immediately after adding and before any irradiation, can lead to an increase in baseline values of the DDSB by as much as 90\% (Parvez et al., 1987; Schmid \& Bauchinger, 1976; Wang et al., 2017). In trials various types of iodine contrast agents have been used. All of this suggests that some of the things that are out of the scope of the examinations may be included in the mechanism of action of the ICM. For example, the genetic component, the previous health state of the organism, etc. This can also be influenced by the fact that, in some patients, ICM can maybe bind to some substances in the body and gain the ability to enter into the cells and damage the DNA molecule. Especially when it is known that low osmolality ICM can still cause adverse reactions, vasodilatation and dehydration of the cells (Joubert et al., 2005). The same can be caused if ICM may cause the formation of new complex compounds in the body or may result in the excretion of substances that would otherwise not be excreted and which have the ability to cause damage to the DNA molecule. Of course, the ability of ICM to induce the occurrence of the DDSB can be influenced by the way of storage and use of the ICM itself. Incorrect storage and route of administration cause instability in ICM and formation of iodides, which can lead to damage to DNA molecules (Lobrich et al., 2010). Although most authors agree that damage to the DNA molecule does not occur when the ICM is added before irradiation, especially if the iodine concentration is below $17.5 \mathrm{mg}$ per $\mathrm{mL}$ of blood (Gould et al., 2016), there are still studies that have shown that concentrations of 7.5 and $15 \mathrm{mg}$ iodine per $\mathrm{mL}$ of blood can lead to an increase in DDSB by approximately $38 \%$ (Xue et al., 1994). Our results are comparable to these, since we also received a significant increase in the amount of DDSB when using $7.5 \mathrm{mg}$ iodine per $\mathrm{mL}$ of blood (Figure 6). Additionally, a larger number of DNA-DSBs appeared if ICM was used in concentrations of 30-50 mg per $\mathrm{ml}$ of blood. Depending on the type of study (in vitro or in vivo), as well as the strength of the radiation dose, at this concentration of iodine contrast agent, the increase in the number of DDSB ranged from 28-110\% (Gould et al., 2016; Grudzenski et al., 2009; Pathe et al., 2011; Piechowiak et al., 2015, 
Wang et al., 2017). In addition to increasing the number of DDDS, these iodine contrast concentrations can lead to chromosome aberrations (Adams et al., 1977; Matsubara et al., 1982) and micronuclei (Dawson et al., 1988; Norman et al., 1978; Norman et al., 2001). These examined concentrations cover doses commonly used in medical diagnostic procedures, including doses that are used in heart catheterization in adults (Marenzi et al., 2009), and even heart catheterization in children, where the dose is up to $65 \mathrm{mg}$ iodine $\mathrm{ml}$ of blood (Gould et al., 2016). The maximum allowable amount for the use of iodine contrast agent is $80 \mathrm{mg}$ iodine per $\mathrm{ml}$ of blood (Deinzer et al., 2014).

The cell corrects DDSB type of damage by means of two mechanisms: non-homologous end joining (NHEJ) and homologous recombination (HR) (Rothkamm et al., 2003). When the repair of the DNA damage is complete, loss of $\gamma \mathrm{H} 2 \mathrm{AX}$ will occur (Leatherbarrow et al., 2006). Therefore, the presence of foci and their number directly indicates that there has been no repair of the DNA molecule. All this for the simple reason because removing of the phosphorylated $\gamma \mathrm{H} 2 \mathrm{AX}$ after repairing the DNA damage is a very complex process that require great coordination and involve a large number of enzymes. If $\gamma \mathrm{H} 2 \mathrm{AX}$ remains for more than 20 hours, indicate that an irregular or irreversible repair of damaged DNA (Suzuki et al., 2006) has occurred.

All these facts indicate that the assessment of the impact of the radiation effect during medical diagnostic procedures, in particular CT with or without ICM, cannot be left only to the dosimetry or dose length product (DLP). The latest data suggests that more efforts should be made to make an estimate of benefits versus damage, especially when repetitive irradiation is performed or when CT is used to monitor the effect of therapeutic procedures. Precautions should also be taken in patients in whom a diagnostic procedure should be repeated in a short amount of time, and the iodine contrast agent for certain reasons is still in the body. The same applies to patients receiving therapy that can lead in itself to damage to the DNA molecule (for example radiotherapy, cytostatic drugs or corticosteroids).

\section{Acknowledgements}

This work is part of the Austrian research project "DNA double strand brakes following ionising radiation" carried out by Division of Pediatric Radiology, Department of Radiology, Medical University Graz/A (PedRad Graz) and Division of Pediatric HematoOncology, Department of Pediatrics and Adolescent Medicine, Division of Cell Biology, Histology and Embryology, all at the Medical University of Graz, Austria. For this reason, I would like to express my gratitude to all the employees of these institutions who participated in the achievement of project goals.
Successful achievement of project goals is starting point for the already established Macedonian-Austrian Project "Theoretical studies of DNA damage induced by ionizing radiation through direct exposure, secondary low-energy electrons and molecular radicals".

\section{References}

Adams, F.H., Norman, A., Mello, R.S., Bass, D., 1977. Effect of radiation and contrast media on chromosomes: preliminary report. Radiology 124, 823-826. Available at: https://doi.org/10.1148/124.3.823

Auger, P., 1975. The Auger effect. Surf. Sci. 48(1), 1-8. Available at: https://doi.org/10.1016/0039-6028(75)903064

Barnard, S., Bouffler, S., Rothkamm, K., 2013. The shape of the radiation dose response for DNA double-strand break induction and repair. Genome Integr. 4(1), 1-8. Available at: https://dx.doi.org/10.1186\%2F2041-9414-4-1

Beels, L., Bacher, K., De Wolf, D., Werbrouck, J., Thierens, H., 2009. gamma-H2AX foci as a biomarker for patient X-ray exposure in pediatric cardiac catheterization: are we underestimating radiation risks? Circulation 120(19), 19031909. Available at: https://doi.org/10.1161/CIRCULATIONAHA.109.880385

Beels, L., Bacher, K., Smeets, P., Verstraete, K., Vral, A., Thierens, H., 2012. Dose-length product of scanners correlates with DNA damage in patients undergoing contrast CT. Eur. J. Radiol. 81(7), 1495-1499. Available at: https://doi.org/10.1016/j.ejrad.2011.04.063

Berrington, de G.A., Darby, S., 2004. Risk of cancer from diagnostic X-rays: estimates for the UK and 14 other countries. Lancet 363(9406), 345-351. Available at: https://doi.org/10.1016/S0140-6736(04)15433-0

Brenner, D.J., 2004. Radiation risks potentially associated with low-dose CT screening of adult smokers for lung cancer. Radiology 231(2), 440-445. Available at: https://doi.org/10.1148/radiol.2312030880

Brenner, D.J., Elliston, C.D., 2004. Estimated radiation risks potentially associated with full body CT screening. Radiology 232(3), 735-738. Available at: https://doi.org/10.1148/radiol.2323031095

Brenner, D.J., Hall, E.J., 2007. Computed tomography-an increasing source of radiation exposure. N. Engl. J. Med. 357(22), 2277-2284. Available at: https://doi.org/10.1056/NEJMra072149

Davidson, C.J., Erdogan, A.K., 2008. Contrast media: procedural capacities and potential risks. Rev. Cardiovasc. Med. 9(suppl 1), S24-S34. Available at: http://medreviews.com/journal/reviews-in-cardiovascularmedicine/vol/9/no/100/contrast-media-proceduralcapacities-and-potential-risks

Dawson, P., Penhaligon, M., Smith, E., Saunders, J., 1988. Synergistic cytotoxicity of iodinated contrast agents and Xradiation. Invest. Radiol. 23(suppl 1), S110-S113.

Deinzer, C.K, Danova, D., Kleb, B., Klose, K.J., Heverhagen, J.T., 2014. Influence of different iodinated contrast media on the induction of DNA double-strand breaks after in vitro X-ray irradiation. Contrast Media Mol. Imaging 9(4), 259267. Available at: https://doi.org/10.1002/cmmi.1567 
Doll, R., Wakeford, R., 1997. Risk of childhood cancer from fetal irradiation. Br. J. Radiol. 70(830), 130-139. Available at: https://doi.org/10.1259/bjr.70.830.9135438

Doss, M., 2013. Linear No-threshold model vs. radiation hormesis. Dose-response 11(4), 495-512. Available at: https://dx.doi.org/10.2203\%2Fdose-response.13-005.Doss

Dusaj, R., Reiner, J.S., 2009. Iodinated contrast media-A safety review. US Cardiology 6(2), 97-100.

Fisher-Wellman, K., Bloomer, R.J., 2009. Acute exercise and oxidative stress: a 30 year history. Dynamic Med 8, 1-25. Available at: https://dx.doi.org/10.1186\%2F1476-5918-8-1

Fuchs, V.R., Sox, H.C. Jr., 2001. Physicians' views of the relative importance of thirty medical innovations. Health Aff (Millwood) 20(5), 30-42.

Gilbert, E. S., 2001. Invited Commentary: Studies of Workers Exposed to Low Doses of Radiation. Am. J. Epidemiol. 153(4), 319-322. Available at: https://doi.org/10.1093/aje/153.4.319

Gould, R., McFadden S.L., Horn, S., Prise, K.M., Doyle, P., Hughes, C.M., 2016. Assessment of DNA double-strand breaks induced by intravascular iodinated contrast media following in vitro irradiation and in vivo, during paediatric cardiac catheterization. Contrast Media Mol. Imaging 11(2), 122-9. Available at: https://doi.org/10.1002/cmmi.1671

Grudzenski, S., Kuefner, M.A., Heckmann, M.B., Uder, M., Lobrich, M., 2009. Contrast medium-enhanced radiation damage caused by CT examinations. Radiology 253(3), 706-714. Available at: https://doi.org/10.1148/radiol.2533090468

Grudzenski, S., Raths, A., Conrad, S., Rube, C., Gould, M., 2010. Inducible response required for repair of low-dose radiation damage in human fibroblasts. Proc. Natl. Acad. Sci. USA 107 (32), 14205-14210. Available at: https://dx.doi.org/10.1073\%2Fpnas.1002213107

Gueant-Rodriguez, R.M., Romano, A., Barbaud, A., Brockow, K., Gueant, J.L., 2006. Hypersensitivity reactions to iodinated contrast media. Cur.r Pharm. Des. 12(26), 33593372.

Haaga, J.R., 2001. Radiation dose management: weighing risk versus benefit. American Journal of Roentgenology 177(2), 289-291. Available at: https://doi.org/10.2214/ajr.177.2.1770289

Herzog, P., Rieger, C.T., 2004. Risk of cancer from diagnostic X-rays. Lancet 363(9406), 340-341. Available at: https://doi.org/10.1016/S0140-6736(04)15470-6

https://en.wikipedia.org/wiki/Linear_no-threshold_model. Last accessed: January 18, 2017.

https://en.wikipedia.org/wiki/Buffy_coat. Last accessed: May 10, 2019.

https://en.wikipedia.org/wiki/Computed_tomography_dose_inde x. Last accessed: May 9, 2019.

ICRP, 1991. 1990 Recommendations of the International Commission on Radiological Protection. ICRP Publication 60. Ann. ICRP 21(1-3). Available at: http://www.icrp.org/publication.asp?id=ICRP\%20Publicat ion\%2060

Jeggo, P., Lobrich, M., 2006. Radiation-induced DNA damage responses. Radiation Protection Dosimetry 122(1-4), 124127. Available at: https://doi.org/10.1093/rpd/ncl495

Johnson, J.N., Hornik, C.P., Li, J.S., Benjamin, D.K. Jr, Yoshizumi, T.T., Reiman, R.E., Frush, D.P., Hill, K.D.,
2014. Cumulative radiation exposure and cancer risk estimation in children with heart disease. Circulation 130(2), 161-167. Available at: https://doi.org/10.1161/CIRCULATIONAHA.113.005425

Jost, G., Golfier, S., Pietsch, H., Lengsfeld, P., Voth, M., Schmid, T.E., Eckardt-Schupp, F., Schmid, E., 2009. The influence of $\mathrm{X}$-ray contrast agents in computed tomography on the induction of dicentrics and gammaH2AX foci in lymphocytes of human blood samples. Phys. Med. Biol. 54(20), 6029-6039. Available at: https://doi.org/10.1088/0031-9155/54/20/001

Joubert, A., Biston, M.C., Boudou, C., Ravanat, J.L., Brochard, T., Charvet, A.M., Estève, F., Balosso, J., Foray, N., 2005. Irradiation in presence of iodinated contrast agent results in radio sensitization of endothelial cells: Consequences for computed tomography therapy. Int. J. Radiat. Oncol. Biol. Phys. 62(5), 1486-1496. Available at: https://doi.org/10.1016/j.ijrobp.2005.04.009

Joubert, A., Zimmerman, K.M., Bencokova, Z., Gastaldo, J., Chavaudra, N., Favaudon, V., Arlett, C.F., Foray, N., 2008. DNA double-strand break repair defects in syndromes associated with acute radiation response: at least two different assays to predict intrinsic radiosensitivity? Int. J. Radiat. Biol. 84(2), 107-125. Available at: https://doi.org/10.1080/09553000701797039

Kendall, G., Hughes, J., Oatway, W., Jones, A., 2006. Variations in radiation exposures of adults and children in the UK. J. Radiol. Prot. 26(3), 257-276. Available at: https://doi.org/10.1088/0952-4746/26/3/001

Kinner, A., Wu, W., Staudt, C., Iliakis, G., 2008. Gamma$\mathrm{H} 2 \mathrm{AX}$ in recognition and signaling of DNA double-strand breaks in the context of chromatin. Nucleic Acids Res. 36(17), 5678-5694. Available at: https://doi.org/10.1093/nar/gkn550

Leatherbarrow, E.L., Harper, J.V., Cucinotta, F.A., O’Neill, P., 2006. Induction and quantification of $\gamma-\mathrm{H} 2 \mathrm{AX}$ foci following low and high LET irradiation. Int. J. Radiat. Biol. 82(2), 111-118. Available at: https://doi.org/10.1080/09553000600599783

Linear No Threshold Theory. https://en.wikipedia.org/wiki/Linear_no-threshold_model. Last accessed: January 18, 2017).

Lobrich, M., Rief, N., Kuhne, M., Heckmann, M., Fleckenstein, J., Rube, C., Uder, M., 2005. In vivo formation and repair of DNA double-strand breaks after computed tomography examinations. Proc. Natl. Acad. Sci. USA 102(25), 89848989. Available at: https://doi.org/10.1073/pnas.0501895102

Lobrich, M., Shibata, A., Beucher, A., Fisher, A, Ensminger, M, Goodarzi, A.A., Barton, O., Jeggo, P.A., 2010. gammaH2AX foci analysis for monitoring DNA doublestrand break repair: strengths, limitations and optimization. Cell Cycle 9(4), 662-669. Available at: https://doi.org/10.4161/cc.9.4.10764

Mah, L., Orlowski, C., Ververis, K., Vasireddy, R.S., El-Osta, A., Karagiannis, T.C., 2011. Evaluation of the efficacy of radiation-modifying compounds using gH2AXas a molecular marker of DNA double-strand breaks. Genome Integr. 2(1), 3. Available at: https://doi.org/10.1186/20419414-2-3

Marenzi, G., Assanelli, E., Campodonico, J., Lauri, G., Marana, I., De Metrio, M., Moltrasio, M., Grazi, M., Rubino, M., Veglia, F., Fabbiocchi, F., Bartorelli, A.L., 2009. Contrast 
volume during primary percutaneous coronary intervention and subsequent contrast-induced nephropathy and mortality. Ann. Intern. Med. 150(3), 170-177. Available at: https://doi.org/10.7326/0003-4819-150-3-200902030-00006

Mathews, J.D., Forsythe, A.V., Brady, Z., Butler, M.W., Goergen, S.K., Byrnes, G.B., Giles, G.G., Wallace, A.B., Anderson, P.R., Guiver, T.A., McGale, P., Cain, T.M, Dowty, J.G., Bickerstaffe, A.C., Darby, S.C., 2013. Cancer risk in 680,000 people exposed to computed tomography scans in childhood or adolescence: data linkage study of 11 million Australians. BMJ 346, f2360. Available at: https://doi.org/10.1136/bmj.f2360

Matsubara, S., Suzuki, S., Suzuki, H., Kuwabara, Y., Okano, T., 1982. Effects of contrast medium on radiation-induced chromosome aberrations. Radiology 144(2), 295-301. Available at: https://doi.org/10.1148/radiology.144.2.7089283

National Research Council. 2006. Health Risks from Exposure to Low Levels of Ionizing Radiation: BEIR VII Phase 2. Washington, DC: The National Academies Press. Available at: https://doi.org/10.17226/11340

Nickoloff, E.L., Alderson, P.O., 2001. Radiation exposures to patients from CT: reality, public perception, and policy. AJR Am. J. Roentgenol. 177(2), 285-287. Available at: https://doi.org/10.2214/ajr.177.2.1770285

Norman, A., Adams, F.H., Riley, R.F., 1978. Cytogenetic effects of contrast media and triiodobenzoic acid derivatives in human lymphocytes. Radiology 129(1), 199-203. Available at: https://doi.org/10.1148/129.1.199

Norman, A., Cochran, S.T., Sayre, J.W., 2001. Metaanalysis of increases in micronuclei in peripheral blood lymphocytes after angiography or excretory urography. Radiat. Res. 155(5), 740-743.

Parvez, Z., Kormano, M., Satokari, K., Moncada, R., Eklund, R., 1987. Induction of mitotic micronuclei by X-ray contrast media in human peripheral lymphocytes. Mutat. Res. 188(3), 233-239.

Pathe, C., Eble, K., Schmitz-Beuting, D., Keila, B., Kaestner, B., Voelker, M., Kleb, B., Klose, K.J., Heverhagen J.T., 2011. The presence of iodinated contrast agents amplifies DNA radiation damage in computed tomography. Contrast Media Mol Imaging 6(6), 507-513. Available at: https://doi.org/10.1002/cmmi.453

Pearce, M.S., Salotti, J.A., Little, M.P., McHugh, K., Lee, C., Kim, K.P., Howe, N.L., Ronckers, C.M., Rajaraman, P., Craft, A.W., Parker, L., Berrington de González, A., 2012. Radiation exposure from CT scans in childhood and subsequent risk of leukaemia and brain tumours: A retrospective cohort study. The Lancet 380(9840), 499-505. Available at: https://doi.org/10.1016/S0140-6736(12)60815-0

Piechowiak, E.I., Peter, J.F., Kleb, B., Klose, K.J., Heverhagen, J.T., 2015. Intravenous iodinated contrast agents amplify DNA radiation damage at CT. Radiology 275(3), 692-697. Available at: https://doi.org/10.1148/radiol.14132478

Pradhan, A.K., Nahar, S.N., Montenegro, M., Yu, Y., Zhang, H., Sur, C., Mrozik, M., Pitzer, R.M., 2009. Resonant X-ray enhancement of the auger effect in high-Z atoms, molecules, and nanoparticles: Potential biomedical applications $\dagger$. J. Phys. Chem. A 113(45), 12356-12363. Available at: https://doi.org/10.1021/jp904977z

Rassow, J., Schmaltz, A., Hentrich, F., Streffer, C., 2000. Effective doses to patients from paediatric cardiac catheterization. Br. J. Radiol. 73(866), 172-183. Available at: https://doi.org/10.1259/bjr.73.866.10884731

Roch-Lefevre, S., Mandina, T., Voisin, P., Gaetan, G., Mesa, J.E., Valente, M., Bonnesoeur, P., García, O., Voisin, P., Roy, L., 2010. Quantification of gammaH2AX foci in human lymphocytes: A method for biological dosimetry after ionizing radiation exposure. Radiat. Res. 174(2), 185194. Available at: https://doi.org/10.1667/RR1775.1

Rothkamm, K., Balroop, S., Shekhdar, J., Fernie, P., Goh, V., 2007. Leukocyte DNA damage after multi-detector row CT: a quantitative biomarker of low-level radiation exposure. Radiology 242(1), 244-251. Available at: https://doi.org/10.1148/radiol.2421060171

Rothkamm, K., Horn, S., 2009. Gamma-H2AX as protein biomarker for radiation exposure. Ann. Ist. Super Sanita 45(3), 265-271.

Rothkamm, K., Kruger, I., Thompson, L.H., Lobrich, M., 2003. Pathways of DNA double-strand break repair during the mammalian cell cycle. Mol. Cell. Biol. 23(16), 5706-5715. Available at: https://doi.org/10.1128/mcb.23.16.57065715.2003

Singh, J., Daftary, A., 2008. Iodinated contrast media and their adverse reactions. J. Nucl. Med. Techno.1 36(2), 69-74. Available at: https://doi.org/10.2967/jnmt.107.047621

Schmid, E., Bauchinger, M., 1976. The cytogenetic effect of an $\mathrm{X}$-ray contrast medium in Chinese hamster cell cultures. Mutat. Res. 34 (2), 291-298.

Suzuki, M., Suzuki, K., Kodama, S., Watanabe, M., 2006. Phosphorylated histone $\mathrm{H} 2 \mathrm{AX}$ foci persist on rejoined mitotic chromosomes in normal human diploid cells exposed to ionizing radiation. Radiat. Res. 165(3), 269276. Available at: https://doi.org/10.1667/RR3508.1

Thomsen, H.S., Morcos, S.K., 2003. Contrast media and the kidney: European Society of Urogenital Radiology (ESUR) guidelines. Br. J. Radiol. 76(908), 513-518. Available at: https://doi.org/10.1259/bjr/26964464

United Nations Scientific Committee on the Effects of Atomic Radiation. Sources and effects of ionizing radiation. New York, NY: United Nations, 2000. Available at: https://www.unscear.org/docs/publications/2000/UNSCEA R_2000_Report_Vol.I.pdf

Vandevoorde, C., Gomolka, M., Roessler, U., Samaga, D., Lindholm, C., Fernet, M., Hall, J., Pernot, E., El-Saghire, H., Baatout, S., Kesminiene, A., Thierenset, H., 2015. EPICT: in vitro assessment of the applicability of the gamma$\mathrm{H} 2 \mathrm{AX}$-foci assay as cellular biomarker for exposure in a multicentre study of children in diagnostic radiology. Int. J. Radiat. Biol. 91(8), 653-663. Available at: https://doi.org/10.3109/09553002.2015.1047987

Wakeford, R., 2005. Guest Editorial: The risk to health from exposure to low levels of ionising radiation. Ann. ICRP 35(4), v-vii. https://doi.org/10.1016/j.icrp.2006.01.002

Wang, L., Li, Q., Wang, X.M., Hao, G.Y., Jie-Bao, Hu, S., Hu, C.H., 2017. Enhanced radiation damage caused by iodinated contrast agents during CT examination. Eur. J. Radiol. 92, 72-7. Available at: https://doi.org/10.1016/j.ejrad.2017.04.005

Xue, L.Y., Friedman, L.R., Oleinick, N.L., Chiu, S.M., 1994. Induction of DNA damage in gamma-irradiated nuclei stripped of nuclearprotein classes: differentialmodulation of double-strand break and DNA-protein crosslink formation. Int. J. Radiat. Biol. 66(1), 11-21. 
Zhang, J., He, Y., Shen, X., Jiang, D., Wang, Q., Liu, Q., Fang, W., 2016. $\gamma$-H2AX responds to DNA damage induced by long-term exposure to combined low-dose-rate neutron and $\gamma$-ray radiation. Mutat. Res. Toxicol. Environ.

Mutagen. 795, 36-40. Available at: https://doi.org/10.1016/j.mrgentox.2015.11.004.

\title{
Влијанието на јодините контрастни средства во текот на КТ: Наши искуства - Развој на два компетитивни методи за автоматско квантифицирање на DDSB
}

\author{
Климентина Трајкова ${ }^{1 *}$, Ивана Дилевска ${ }^{1}$, Руменка Петковска $^{2}$, Дејан Трајков ${ }^{1,3}$, \\ Томас Кронајс ${ }^{4}$, Волфганг Швингер ${ }^{5}$, Ерих Сорантин ${ }^{1}$ \\ ${ }^{I}$ Division of Pediatric Radiology, Department of Radiology, Medical University Graz, \\ Auenbruggerplatz 34 A - 8036, 8010 Graz, Austria \\ ${ }^{2}$ Институт за применета хемија и фармацевтски анализи, Фармацевтски факултет, \\ Универзитет „Кирил и Методиј”, Мајка Тереза 47, 1000 Скопје, \\ Република Северна Македонија \\ ${ }^{3}$ Институт за имунобиологија и хумана генетика, Медииински факултет, \\ Универзитет „Св. Кирил и Методиј”, 50 дивизија 6, 1000 Скопје, \\ Република Северна Македонија \\ ${ }^{4}$ Division of Cell Biology, Histology and Embryology, Gottfried Schatz Research Center, \\ Medical University Graz, Neue Stiftingtalstraße 6, 8010 Graz, Austria \\ ${ }^{5}$ Division of pediatric hematology/oncology, \\ Department of Paediatrics and Adolescent Medicine, Medical University Graz, \\ Auenbruggerplatz, 34/2 - 8036, 8010 Graz, Austria
}

Клучни зборови: КТ испитувања, ICM, имунофлуоресценција, проточна цитометрија, DDSB

Оштетувањето на ДНК молекулата предизвикано од јонизирачко зрачење може во крајна линија да доведе до смрт на клетките или да иницира развој на карцином. Многу е тешко да се процени каква ќе биде вистинската штета која ќe се предизвика кај човечкото тело, имајќи го во предвид фактот дека денес во светот се повеќе се зголемува употребата на дијагностички методи кои користат зрачење и јодни контрастни средства, како и тоа дека постојат голем број на фактори кои можат да влијаат на доза на озрачување ин виво. Во исто време потребено е да се развијат нови методи со кои, за многу пократок временски период, ќе може да се одреди каков ќе биде ефектот на дијагностичкото зрачење врз ДНК молекулата. За овие цели ние развивме две компетитивни методи за автоматско квантифицирање на двојните прекини во ДНК молекулата (DDSB) во лимфоцитите од периферната крв: имунофлуоресцентно одредување на $\gamma \mathrm{H} 2 \mathrm{AX}$ со обоени микроскопски слајдови и одредување на појава на DDSB со проточна цитометрија. Нашите првични резултати покажаа дека компјутерската томографија (KT) може да предизвика оштетување на ДНК молекулата во форма на DDSB, на постоење на линеарна зависност со зголемување на нискиот и висок опсег на дозниот индекс кај КТ (CTDI) и бројот на $\gamma \mathrm{H} 2 \mathrm{AX}$, како и дека употребата на јодни контрастни средства доведува до зголемена појава двојни прекини во ДНК молекулата. 
